\title{
Sweat and heat production related to air humidity during exercise and inactive recovery - a laboratory study
}

\author{
Erik U Høye ${ }^{1,2}$, Mariann Sandsund ${ }^{1 *}$, Randi Eidsmo Reinertsen ${ }^{1}$ \\ From 15th International Conference on Environmental Ergonomics (ICEE XV) \\ Portsmouth, UK. 28 June - 3 July 2015
}

\begin{abstract}
Introduction
Certain occupational groups are exposed to unfavourable work conditions, such as exposure to warm and humid environments and alternations between high and low work intensity. Such conditions affect thermoregulatory responses as well as thermal sensation and comfort. Exercise and work capacity at moderate intensity in a warm environment are progressively impaired as relative humidity (rh) increases [1]. However, the influence of relative humidity on regional sweat rate (RSR) during high-intensity work followed by a recovery period has not been studied. This study examines the relationship between rh and RSR during inactive recovery after a period of high work intensity.
\end{abstract}

\section{Methods}

We measured RSR in 10 healthy male subjects aged between 20 and 30 by means of absorbent pads, in two trials performed at SINTEF's Work Physiology Laboratory. The trials consisted of running for $20 \mathrm{~min}$ at $68(4) \%$ $\mathrm{VO}_{2 \max }$ followed by $30 \mathrm{~min}$ of inactive recovery at 19 and $85 \%$ rh at $30{ }^{\circ} \mathrm{C}$ and $0(0.2) \mathrm{m} . \mathrm{s}^{-1}$ air velocity. Nude body mass, rectal $\left(\mathrm{T}_{\mathrm{re}}\right)$ and local skin $\left(\mathrm{T}_{\mathrm{s}}\right)(6$ sites) temperatures (YSI $400(0.15){ }^{\circ} \mathrm{C}$ ), heart rate (HR) (Polar S810 ${ }^{\mathrm{TM}}$ Electro OY), oxygen consumption (Oxycon Pro, Cardinal Health) and RSR on the central mid-back and posterior-forearm (Air Laid, Meditas) were measured. The method of measuring RSR by means of absorbent pads was modified from Smith and Havenith [2]. Starting with the last five minutes of running, the absorbent pads were changed every five min. After the inactive recovery phase, nude

\footnotetext{
* Correspondence: Mariann.Sandsund@sintef.no

'SINTEF Technology and Society, Department of Health Research,

Trondheim, Norway

Full list of author information is available at the end of the article
}

body mass was measured again in order to estimate gross sweat loss (GSL).

\section{Results}

GSL was higher at $85 \%$ rh (796(414) g.h $\left.{ }^{-1}\right)$ than at $19 \%$ rh $\left(489(140)\right.$ g.h $\left.^{-1}\right)(\mathrm{p}<0.05)$. RSR on the back was $1105(95 \% \mathrm{CI}, 691$ to 1765$) \mathrm{g} \cdot \mathrm{m}^{-2} \cdot \mathrm{h}^{-1}$ during the first five min of recovery at $85 \% \mathrm{rh}$. At $19 \% \mathrm{rh}$, RSR was 675(417 to 1093$) \mathrm{g} \cdot \mathrm{m}^{-2} \cdot \mathrm{h}^{-1}$ for the same time interval, which was significantly lower $(\mathrm{p}<0.05)$. RSR on the back fell to 395(227 to 686) and 165(113 to 240) g.m $\mathrm{m}^{-2} \cdot \mathrm{h}^{-1}$ at $85 \%$ and $19 \%$ rh during the last five min of recovery ( $\mathrm{p}<0.05)$. The corresponding RSR on the arm was 459(573 to 367) and 225(171 to 296) g.m $\mathrm{m}^{-2} \cdot \mathrm{h}^{-1}$ at $85 \%$ rh, and 216(155 to 300) and 16(6 to 48$)$ g.m $\mathrm{m}^{-2} \cdot \mathrm{h}^{-1}$ at $19 \% \mathrm{rh}$ $(\mathrm{p}<0.05)$. RSR showed weak to strong correlations with $\mathrm{T}_{\mathrm{s}}$ during recovery, but not during exercise. $\mathrm{T}_{\mathrm{re}}$ continued to increase for seven and three minutes post-exercise at $85 \%$ and $19 \%$ rh. HR was 11 b.min ${ }^{-1}$ higher after exercise and during the first twenty min of recovery at $85 \%$ compared to $19 \% \mathrm{rh}(\mathrm{p}<0.05)$.

\section{Discussion}

The differences in RSR were in accordance with the results of Smith and Havenith [2]. Our findings indicate a prolonged sweat response at $85 \%$ rh compared to $19 \% \mathrm{rh}$. This corresponds to the continued increase in $\mathrm{T}_{\mathrm{re}}, \mathrm{T}_{\mathrm{s}}$ and a higher $\mathrm{HR}$ post-exercise at $85 \% \mathrm{rh}$, indicating a higher thermal load.

\section{Conclusion}

Thermal load measured by RSR, HR, $\mathrm{T}_{\mathrm{re}}$ and $\mathrm{T}_{\mathrm{s}}$ was higher during post-exercise inactive recovery at $85 \% \mathrm{rh}$ compared to $19 \%$ rh at $30{ }^{\circ} \mathrm{C}$. This study emphasizes the 
importance of including the effect of rh in assessments of work in hot environments.

\section{Acknowledgements}

The project is being funded by the Research Council of Norway. Project period: June 2013-2016

\section{Authors' details}

${ }^{1}$ SINTEF Technology and Society, Department of Health Research, Trondheim, Norway. ${ }^{2}$ Norwegian University of Science and Technology,

Department of Biology, Trondheim, Norway.

Published: 14 September 2015

\section{References}

1. Maughan RJ, Otani H, Watson P: Influence of relative humidity on prolonged exercise capacity in a warm environment. Eur J Appl Physiol 2012, 112:2313-2321.

2. Smith CJ, Havenith G: Body mapping of sweating patterns in male athletes in mild exercise-induced hyperthermia. Eur J Appl Physiol 2010, 111:1391-1404.

doi:10.1186/2046-7648-4-S1-A146

Cite this article as: Høye et al: Sweat and heat production related to air humidity during exercise and inactive recovery - a laboratory study. Extreme Physiology \& Medicine 2015 4(Suppl 1):A146.

\section{Submit your next manuscript to BioMed Central} and take full advantage of:

- Convenient online submission

- Thorough peer review

- No space constraints or color figure charges

- Immediate publication on acceptance

- Inclusion in PubMed, CAS, Scopus and Google Scholar

- Research which is freely available for redistribution

Submit your manuscript at www.biomedcentral.com/submit 